\title{
Detection of Aflatoxin Contamination of Dairy Production Chain in the Northwest Region of Rio Grande do Sul, Brazil
}

\author{
Patrícia Wolkmer ${ }^{1}$, Daniele Furian Araldi ${ }^{1}$, Josué Olivo Oliveira do Prado ${ }^{2}$, Camila da Rosa Carnelosso², \\ Jaine Muhl ${ }^{2}$, Jamile Hasan ${ }^{1}$, Heloisa Palma ${ }^{1} \&$ Lucas Carvalho Siqueira ${ }^{1,2}$ \\ ${ }^{1}$ Veterinary Medicine, University of Cruz Alta, Rio Grande do Sul, Brazil \\ ${ }^{2}$ Rural Development Post-graduation Program, University of Cruz Alta, Rio Grande do Sul, Brazil \\ Correspondence: Lucas Carvalho Siqueira, Veterinary Medicine, University of Cruz Alta (UNICRUZ), Campus \\ Rodovia Municipal Jacob Della Méa, km 5.6, Parada Benito Cruz Alta, Rio Grande do Sul, CEP: 98005-972, \\ Brazil. E-mail: lusiqueira@unicruz.edu.br
}

Received: April 29, 2018

doi:10.5539/jas.v10n8p260
Accepted: May 31, $2018 \quad$ Online Published: July 15, 2018

URL: https://doi.org/10.5539/jas.v10n8p260

The research is financed by Fundação de Amparo à Pesquisa do Estado do Rio Grande do Sul (Fapergs) and Nutrifarma.

\begin{abstract}
The present study evaluates levels of aflatoxin contamination involving small dairy farms from the in the Northwest region of Rio Grande do Sul, Brazil. The objectives of this trial is: quantify lactating cow diet and raw for bulk milk Aflatoxin B1 (AFB1) contamination; evaluate the use of a mycotoxin adsorbent on cows submitted to semi-confinement raising; and verify the presence of AFM1 contamination on UHT and powdered milk commercialized locally. For this, 17 farms were selected. During the experimental period, every lactating cow on each herd received $50 \mathrm{~g}$ /day of a commercial mycotoxin adsorbent for dairy cows ( $100 \%$ bentonite). From each farm, bulk milk, corn silage and concentrate samples were collected for aflatoxin quantification. Aflatoxin M1 was detected in all milk samples examined from each farm, but the levels were within the allowed by the legislation. Aflatoxin B1 was also detected in all samples of corn silage and concentrate. The mycotoxin adsorbent used reduced $(\mathrm{p}<0.05)$ AFM1 contamination in milk. AFM1 milk contamination levels observed on commercialized milk also respected Brazilian requirements. It is possible to conclude that there is a high incidence of Aflatoxin B1 contamination on corn silage and dairy cows concentrates in family farms from South Brazil region. Based on the condition in which the present study was conducted, the use of a mycotoxin adsorbent reduced the levels of AFM in milk in production system. However, the locally produced milk and commercial milk were below the AFM levels accepted by the National Requirements for AFM1 contamination.
\end{abstract}

Keywords: mycotoxin, adsorbent, concentrate, silage, milk

\section{Introduction}

Mycotoxins are secondary metabolites with low molecular weight produced by a wide range of filamentous fungi present in many animal feeds, including bulky and concentrated food (Bhatnagar et al., 2002; Gallo et al., 2015). Of these, those that have the greatest negative effect on dairy farming include aflatoxin, ochratoxin, vomitoxin, deoxynivalenol, zearalenone and fumonisin (Fink-Gremmels, 2008). Among all aflatoxins, the most important are classified as B1, B2, G1 and G2; they are secondary metabolites produced by the fungi Aspergillus flavus and Aspergillus parasiticus (Wilson \& King, 1995).

The most abundant aflatoxin present in naturally contaminated foods is type B1 (AFB1) (Gallo et al., 2015). The toxic effects secondary to the consumption of the contaminated feed occur due to damage to the liver and cause reduction of growth rate, milk production, milk quality and reduction of resistance to infectious diseases (Pier, 1992; Abeni et al., 2014). Ruminants are more resistant to aflatoxin than monogastric animals, this is due to biotransformations that these animals can perform. When fed AFB1-contaminated foods, they are biotransformed metabolically in the hydroxylated form aflatoxin M1 (AFM1) by the enzyme cytochrome P and are excreted in the milk of lactating animals (Kuilman et al., 2000; Wu et al., 2009).

Thus, in addition to the economic damages related to animal production, these toxins are of great importance for 
public health. Its properties, toxic to humans, have a broad spectrum, with special attention to the carcinogenic effects (Ross et al., 1992; Chawanthayatham et al., 2017). AFM1 is allocated to the human carcinogenic group 1 by the International Agency for Research on Cancer (Bosch \& Peers, 1991; IARC, 2012; Ostry et al., 2017).

In order to reduce the deleterious effects of aflatoxins, it has been proposed the use of additives such as adsorbents mixed with animal feed, which are able to decrease the absorption of mycotoxins. When added to the feed, such products are intended to bind to mycotoxins in order to transport them fully or partially out of the digestive tract, thereby preventing the absorption and intoxication of the animals (Kabak et al., 2006; Xiong et al., 2015; Nidhina et al., 2017). However, the use of inorganic adsorbents may reduce the nutrient density of the diet, as well as promote an excess of absortion capacity that may lead to a decrease in the availability of important microelements (Rabiee et al., 2010).

Given this scenario, this work aimed to analyze the chain that involves the occurrence of aflatoxins in the Alto Jacuí region, Northwest of Rio Grande do Sul (RS), Brazil. For this, studies were carried out to reach the following objectives: quantify the levels of AFB1 in the feed supplied to dairy cows and their reflection on the levels of AFM1 in raw milk produced in family farms of the RS region. A second objective of this study was also to evaluate the effect of the use of an adsorbent additive of mycotoxins in the milk produced in the facilities. The last objective was also to verify the presence of AFM1 in different brands of UHT and powdered milk commercialized in the region, comparing the results obtained with the current legislation.

\section{Material and Methods}

\subsection{Place of Experiment}

To perform this study, 17 milk-producing farms were selected, located in six counties in the Northwest region of the State of RS, Brazil, these farms represented a representative sample of Alto Jacuí region, as they have representative characteristics of the region, as described by Lorenzoni, Araldi, and Mera (2012). The properties had up to 50 hectares dedicated to milk production, herds with up to 20 lactating cows, semi-confinement systems, two daily milking and family labor. These properties did not receive regular technical assistance and did not evaluate the raw material supplied to the animals. According to the authors, the average daily milk production was between 18 and 403 liters, per cow and per property, respectively.

In the farm selected for the study, the diet offered to the animals consisted of commercial protein concentrate or locally produced concentrate, corn silage, pastures grown in autumn-winter: black oats (Avena strigosa), white oats (Avena sativa) and ryegrass (Lolium multiflorum); and in the summer: sorghum (Sorghum bicolor) and millet (Pennisetum americanum). In all the evaluated properties, the concentrate was supplied individually in feed fences, in two daily meals. The milking was done in closed system with proper milking management and milk production occurred throughout the year.

\subsection{Supply of Adsorbent}

The mycotoxin adsorbent additive was supplied during the 10-day experimental period to all lactating cows. The animals received $50 \mathrm{~g}$ of a commercial adsorbent approved for use in lactating cows, composed of $100 \%$ bentonite (Toxfree MilkPower ${ }^{\circledR}$ Nutrifarma). The product was given orally, once a day (at the first meal), individually, mixed into the concentrate.

\subsection{Sample Collection}

In each farm silage samples were collected on days 0 and 5 of the experimental period in nine distinct points of the silo: three points of the upper third of the silo, three points of the middle third and three points of the lower third. The material was homogenized and the analysis performed in an aliquot of 100 grams, representative of the exposed face of the silo. The samples were stored in plastic containers and stored at $-20{ }^{\circ} \mathrm{C}$ until processed.

The collection of samples of concentrated ration was performed on days 0 and 5 of the experimental period. Samples were collected directly from the sheds where food was stored. The bags destined to the next feeding of the animals were selected, and 5 samples were collected at random points of the bags. All samples were frozen immediately until analysis.

Samples of raw milk were collected on days $-4,-2,0$ and 5 of the experimental period, directly from the expansion tanks after milking the animals, cooling to $4{ }^{\circ} \mathrm{C}$ and homogenization. Three samples of milk per property were collected. The samples were stored in $70 \mathrm{ml}$ sterile tubes and immediately frizzed at $-20^{\circ} \mathrm{C}$ and then sent to the laboratory for analysis.

\subsection{Analysis of Milk Marketed in the Region}

Samples of milk marketed in regional establishments were purchased from boxes of 1 liter of UHT milk from 13 
different trade marks and from 500 grams of milk powder from 4 commercial brands.

\subsection{Aflatoxin Analysis}

Aflatoxin analyzes were performed in a laboratory accredited to the Brazilian Ministry of Agriculture, Livestock and Supply (MAPA) (Note 1). The quantification of AFM1 in the milk was performed in laboratory accredited to the MAPA by Mass Spectrophotometry (HPLC/MSMS). For the quantification of Aflatoxin B1 in the silage and sample of concentrate, the enzyme immunoassay technique (ELISA) was performed.

\subsection{Analysis of Milk Quality}

Samples for analysis of milk quality were collected on days 0 (start of administration of the adsorbent), days 5 and 10 of the experimental period, in $60 \mathrm{ml}$ capacity tubes containing one tablet with $8 \mathrm{mg}$ of 2-bromo-2-nitropropane-1, 3-diol and $0.3 \mathrm{mg}$ of the antifungal agent natamicime. The samples were homogenized and sent for analysis of their composition: fat, protein, lactose, casein, total solids, non-greasy solids, somatic cell count (CCS) and urea nitrogen (NUL). The composition and urea nitrogen were analyzed by the infrared method on Bentley 2000 equipment and the somatic cell count by flow cytometry (Somacount 300, from Bentley Instruments, Inc.).

\section{Results and Discussion}

When considering the 17 samples of concentrate and silage destined to the consumption of dairy cattle in the region of Corede Alto Jacuí, in all of them it was possible to detect the presence of AFB1 (Figure 1). However, the analysis of aflatoxin level results should be based on the current Brazilian legislation, since the maximum permitted aflatoxin limit on grains varies according to the legislation of each country. MAPA adopts the limit of $50 \mu \mathrm{g} / \mathrm{kg}$ for feed destined for animal consumption (direct intake or feed raw material) (Brazil, 2002). However, the legislation common to countries of Mercosur, which Brazil is part of, follows the limits established by National Health Surveillance Agency (ANVISA) (Note 2) (Brazil, 2011), where the maximum permitted limit of aflatoxin is $20 \mu \mathrm{g} / \mathrm{kg}$ of food such as corn used for animals.

\section{Aflatoxin B1 in commercial feed (concentrate) sample}

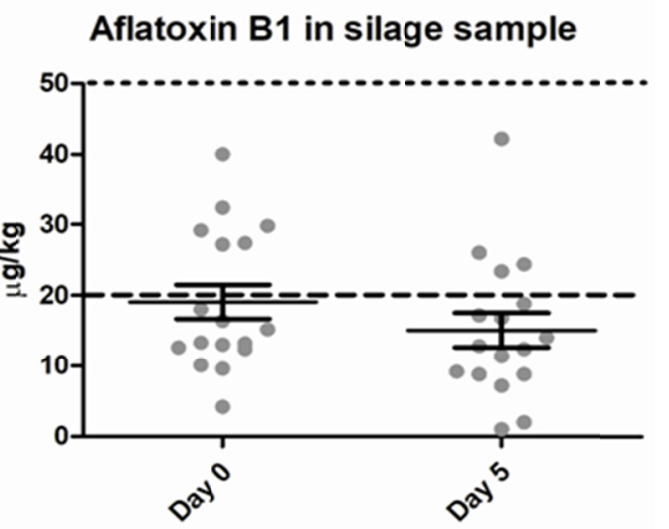

Figure 1. Detected levels of aflatoxins B1 (AFB1) in samples of concentrate (A) and silage (B), collected in production facilities of milk type B, in 6 municipalities of the Northwest region of Rio Grande do Sul - Brazil. Individual values and mean \pm standard deviation $(\mathrm{n}=17)$. the line at the top of the graph - - - represents maximum levels of Brazilian legislation, limit of AFB1 $50 \mu \mathrm{g} / \mathrm{kg}$ of food; he line in the middle of the graph - - represents maximum levels of MERCOSUR legislation, AFB1 limit $20 \mu \mathrm{g} / \mathrm{kg}$ of food

In the silage samples the AFB1 contamination ranged from 1.0 to $42.0 \mu \mathrm{g} / \mathrm{kg}$, (mean $17.14 \pm 9.726 \mu \mathrm{g} / \mathrm{kg}$ ) and $47.06 \%(8 / 17)$ of the samples presented values above the limit established by ANVISA. Regarding the evaluation of the commercial concentrates, the presence of the toxin was found to be above the limit established by ANVISA at $11.76 \%(2 / 17)$, however the AFB1 levels observed in the concentrate samples remained below the recommended tolerance limit for Feed raw material in Brazil. Being a potent hepatotoxin and carcinogen, AFB1 appears to be a common contamination in food, especially in the silage used as animal feed in the analyzed region. In addition, mycotoxins present in the diet seem to negatively influence animal production and health (Pier, 1992; Masoero et al., 2007; Sulzberger et al., 2017). However, hepatic metabolism of AFB1 to AFM1 in 
milk occurs in the animal, resulting in preventive decontamination triggered by the animal. The AFM1 found in bovine milk is about ten times less toxic than AFB1 (Fink-Gremmels, 2008; Gallo et al., 2015).

From the samples of raw milk collected before the adsorbent was supplied, in the 3 replicates, the contamination by AFM1 (Figure 2), which varied from 0.013 to $0.227 \mu \mathrm{g} / \mathrm{L}(0.059 \pm 0.0627)$, was detected in $88 \%(15 / 17) 0$ of the cases. However, the values obtained meet the standards established by the current legislation, which establishes as maximum concentration of AFM1 in milk $0.5 \mu \mathrm{g} / \mathrm{L}$ (Brazil, 2002). Despite this, it is important to enphasize the chronic and carcinogenic effect of aflatoxin. The absorption of aflatoxins with the diet, even the regular absorption of small amounts, poses serious health risks.

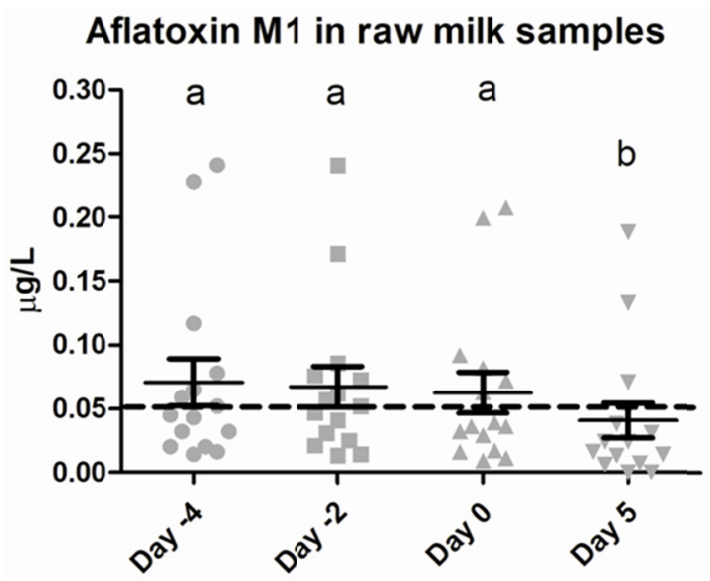

Figure 2. Detection levels of aflatoxins M1 in raw milk samples collected in the expansion tank before (Days -4, -2 and 0 ) and after (Day 5) the oral administration of 50g per day of mycotoxin adsorbent to dairy cows in producton. Experiment conducted on type B milk producing properties, in municipalities of the Northwest region of Rio Grande do Sul, Brazil. Individual values and mean \pm standard deviation were presented. Different letters represent a significant statistical difference $(\mathrm{P}<0.05, \mathrm{n}=17)$. Line - - - represents maximum levels of MERCOSUR legislation, AFB1 limit $20 \mu \mathrm{g} / \mathrm{L}$ of milk

Aflatoxins are potent and naturally occurring carcinogenic mycotoxins with a genotoxic effect and chronic liver toxicity, especially in combination with hepatitis (Bosch \& Peers, 1991; Ostry et al., 2017; Zhang et al., 2017). Aflatoxins are classified as Group 1 carcinogens by the FAO because they lead to liver cancer (Bosch \& Peers, 1991; Kucukcakan \& Hayrulai-Musliu, 2015; Ostry et al., 2017). Milk is the main source of nutrients for children and is also of great importance in all stages of a human being's life, as it contains a wide variety of nutrients essential for the growth, development and maintenance of a healthy life. When contaminated with mycotoxins may result in developmental disability and câncer (Oliveira et al., 1997; Tchana et al., 2010).

Detection of AFB1 in animal feed may have contributed to the occurrence of the toxin in the milks. In this way the use of guaranteed quality raw material and the adequate storage of silage and concentrate are important. The silage production influences aflatoxin levels, because if anaerobic conditions are not reached and maintained, Clostridium sp., yeasts and fungi can proliferate (Carvalho et al., 2016; del Palacio et al., 2016). Thus, although the results found in cattle feeding are in accordance with the Brazilian legislation $(50 \mu \mathrm{g} / \mathrm{kg})($ Brazil, 2002), it seems not to be adequate to prevent the occurrence of AFM1 in milk.

Searching for alternatives for the reduction of aflatoxin levels in the milk in the farms, $50 \mathrm{~g}$ of commercial adsorbent was supplied, once a day, to the animals. Under the conditions evaluated in the present study, the addition of mycotoxin adsorbents in the cow's diet for a period of 5 days reduced AFM1 concentrations in milk (Figure 2) $(\mathrm{P}<0.05 ; 0.059 \pm 0.06$ and $0.036 \pm 0.05)$. In the $15 \mathrm{farms}, 93.3 \%(14 / 15)$ of the samples where the toxin was detected in the milk occurred a mean reduction of $50.5 \%(\mathrm{WMD}=29.6 ; \mathrm{CV}=59.7)$ of the levels of contamination by AFM1 After the use of the adsorbent. In only one property there was an increase in the detected levels of contamination. This absorption factor is attributed to its high electrolytic affinity for high polar mycotoxins, such as aflatoxin (Huwig et al., 2001). Also, the use of the adsorbent did not generate significant variations as regards the quality and composition of the milk $(\mathrm{P}>0.05)$, maintaining the characteristic of the milk in the analyzed properties. 
Considering the contamination of aflatoxin found in raw milk, it was also sought to analyze the contamination in milk commercialized in the region. Of the 13 commercially available whole milk samples, all $(100 \%)$ were positive for the presence of AFM1, with values obtained within the limit required by Brazilian legislation $(0.5$ $\mu \mathrm{g} / \mathrm{L}$ ) (Figure 3). However, only 23.07\% (3/13) of these samples would meet European Union requirements $(0.05 \mu \mathrm{g} / \mathrm{L})$. Of the 4 samples of powdered milk analyzed, $3(75 \%)$, presented AFM1, but all were within the amount required by national legislation (Figure 4). Thus, it can be suggested that the export of milk from Brazil to the European Union can be impaired because, even if the presence of this toxin is within the limit acceptable by Brazilian legislation, the European limit is more rigid than the Brazilian one. This fact would impede marketing between both continents.

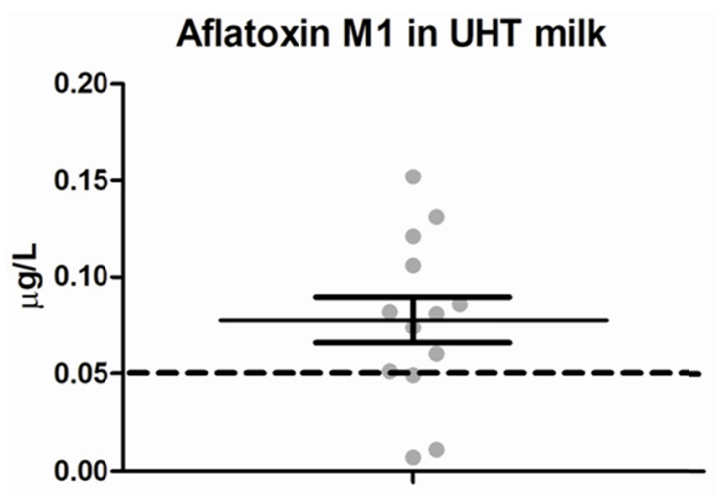

Figure 3. Detection of M1 aflatoxins in UHT milk samples commercialized in the municipalities of the Northwest region of Rio Grande do Sul - Brazil. Individual values and mean \pm standard deviation $(\mathrm{n}=13)$ were presented. Line - - - represents maximum levels of MERCOSUR legislation, AFB1 limit $20 \mu \mathrm{g} / \mathrm{L}$ of milk

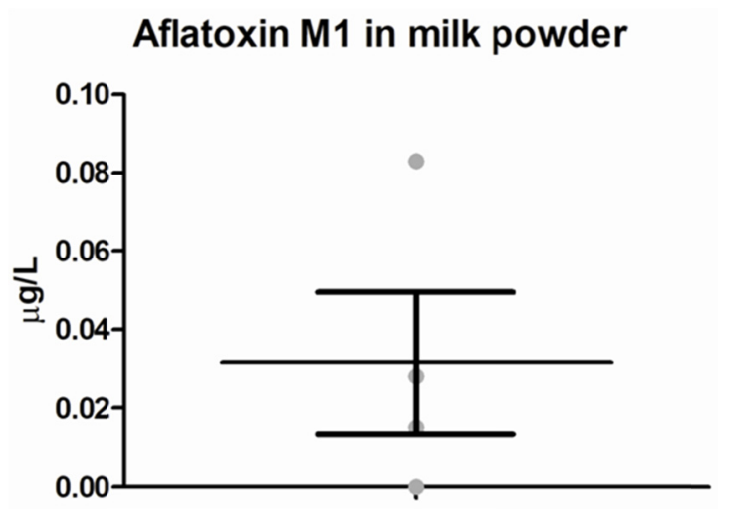

Figure 4. Detection of M1 aflatoxins in powdered milk samples commercialized in the municipalities of the Northwest region of Rio Grande do Sul - Brazil. Individual values and mean \pm standard deviation $(n=13)$ were presented. MERCOSUR legislation the AFB1 limit $20 \mu \mathrm{g} / \mathrm{L}$ of milk

\section{Conclusions}

Under the conditions evaluated, we conclude that $88 \%$ of the milk samples collected in the family properties of the Alto Jacuí-RS region presented contamination with Aflatoxin M1. However, the levels of contamination observed are within the standards levels required by the Brazilian legislation. In $93.3 \%$ of the cases in which contamination occurred, the use of the mycotoxin adsorbent reduced the concentrations of Aflatoxin M1 in milk in half.

\section{Referencies}

Abeni, F., Migliorati, L., Terzano, G. M., Capelletti, M., Gallo, A., Masoero, F., \& Pirlo, G. (2014). Effects of two different blends of naturally mycotoxin-contaminated maize meal on growth and metabolic profile in replacement heifers. animal, 8, 1667-1676. doi:10.1017/S1751731114001475 
Brazil. (2011). Resolução no 7 de 18/02/2011. ANVISA (Agência Nacional de Vigilância Sanitária). Retrieved from http://www.diariodasleis.com.br/busca/exibelink.php?numlink=216390

Brazil. (2002). Aprova os regulamentos técnicos de produção, identidade e qualidade do leite tipo (Seção 1. p. 13). Instrução Normativa $n^{\circ}$ 51, de 20 de setembro de 2002. MAPA (Ministério Agricultura, Pecuária e Abastecimento), Diário Oficial da União, Brasília.

Bhatnagar, D., Yu, J., \& Ehrlich, K. C. (2002). Toxins of filamentous fungi. Chemical Immunology, 81, $167-206$. https://doi.org/10.1159/000058867

Bosch, F. X., \& Peers, F. (1991). Aflatoxins: Data on human carcinogenic risk. IARC Sci Publ, 48-53.

Carvalho, B. F., Ávila, C. L. S., Krempser, P. M., Batista, L. R., Pereira, M. N., \& Schwan, R. F. (2016). Occurrence of mycotoxins and yeasts and moulds identification in corn silages in tropical climate. Journal of Applied Microbiology, 120, 1181-1192. https://doi.org/10.1111/jam.13057

Chawanthayatham, S., Valentine, C. C., Fedeles, B. I., Fox, E. J., Loeb, L. A., Levine, S. S., ... Essigmann, J. M. (2017). Mutational spectra of aflatoxin B1 in vivo establish biomarkers of exposure for human hepatocellular carcinoma. Proceedings of the National Academy of Sciences of the United States of America, 114, E3101-E3109. https://doi.org/10.1073/pnas.1700759114

Fink-Gremmels, J. (2008). Mycotoxins in cattle feeds and carry-over to dairy milk: A review. Food Additives and Contaminants-Part A Chemistry, Analysis, Control, Exposure and Risk Assessment, 25, 172-180. https://doi.org/10.1080/02652030701823142

Gallo, A., Giuberti, G., Frisvad, J. C., Bertuzzi, T., \& Nielsen, K. F. (2015). Review on mycotoxin issues in ruminants: Occurrence in forages, effects of mycotoxin ingestion on health status and animal performance and practical strategies to counteract their negative effects. Toxins, 7, 3057-3111. https://doi.org/10.3390/ toxins 7083057

IARC. (2012). Aflatoxins. IARC Monographs on the Evaluation of Carcinogenic Risks on Humans (100 F, pp. 225-248).

Kabak, B., Dobson, A. D. W., \& Var, I. (2006). Strategies to prevent mycotoxin contamination of food and animal feed: A review. Critical Reviews in Food Science and Nutrition, 46, 593-619. https://doi.org/ $10.1080 / 10408390500436185$

Kucukcakan, B., \& Hayrulai-Musliu, Z. (2015). Challenging Role of Dietary Aflatoxin B1 Exposure and Hepatitis B Infection on Risk of Hepatocellular Carcinoma. Open Access Macedonian Journal of Medical Sciences, 15, 363-369. https://doi.org/10.3889/oamjms.2015.032

Kuilman, M. E. M., Maas, R. F. M., \& Fink-Gremmels, J. (2000). Cytochrome P450-mediated metabolism and cytotoxicity of aflatoxin B1 in bovine hepatocytes. Toxicology in Vitro, 14, 321-327. https://doi.org/ 10.1016/S0887-2333(00)00025-4

Lorenzoni, A., Araldi, D. F., \& Mera, C. M. P. de. (2012). Diagnóstico das Unidades de Produção Leiteira dos Municípios da Região do Corede Alto Jacuí-RS (p. 158). Cruz Alta: UNICRUZ.

Masoero, F., Gallo, A., Moschini, M., Piva, G., \& Diaz, D. (2007). Carryover of aflatoxin from feed to milk in dairy cows with low or high somatic cell counts. Animal: An International Journal of Animal Bioscience, 1(9), 1344. https://doi.org/10.1017/S1751731107000663

Nidhina, N., Bhavya, M. L., Bhaskar, N., Muthukumar, S. P., \& Murthy, P. S. (2017). Aflatoxin production by Aspergillus flavus in rumen liquor and its implications. Food Control, 71, 26-31. https://doi.org/ 10.1016/j.foodcont.2016.05.051

Oliveira, C. A. F., Germano, P. M. L., Bird, C., \& Pintot, C. A. (1997). Immunochemical assessment of aflatoxin M1 in milk powder consumed by infants in São Paulo, Brazil. Food Additives and Contaminants, 14, 7-10. https://doi.org/10.1080/02652039709374491

Ostry, V., Malir, F., Toman, J., \& Grosse, Y. (2017). Mycotoxins as human carcinogens-The IARC Monographs classification. Mycotoxin Research, 33, 65-73.

del Palacio, A., Mionetto, A., Bettucci, L., \& Pan, D. (2016). Evolution of fungal population and mycotoxins in sorghum silage. Food Additives and Contaminants-Part A Chemistry, Analysis, Control, Exposure and Risk Assessment, 33, 1864-1872. https://doi.org/10.1080/19440049.2016.1244732

Pier, A. C. (1992). Major biological consequences of aflatoxicosis in animal production. Journal of Animal 
Science, 70, 3964-3967.

Rabiee, A. R., Lean, I. J., Stevenson, M. A., \& Socha, M. T. (2010). Effects of feeding organic trace minerals on milk production and reproductive performance in lactating dairy cows: A meta-analysis. Journal of Dairy Science, 93, 4239-4251. https://doi.org/10.3168/jds.2010-3058

Ross, R. K., Yuan, J. M., Yu, M. C., Wogan, G. N., Qian, G. S., Tu, J. T., ... Henderson, B. E. (1992). Urinary aflatoxin biomarkers and risk of hepatocellular carcinoma. Lancet, 339, 943-6. https://doi.org/ 10.1016/0140-6736(92)91528-G

Sulzberger, S. A., Melnichenko, S., \& Cardoso, F. C. (2017). Effects of clay after an aflatoxin challenge on aflatoxin clearance, milk production, and metabolism of Holstein cows. Journal of Dairy Science, 100, 1856-1869.

Tchana, A. N., Moundipa, P. F., \& Tchouanguep, F. M. (2010). Aflatoxin contamination in food and body fluids in relation to malnutrition and cancer status in Cameroon. International Journal of Environmental Research and Public Health, 7, 178-188. https://doi.org/10.3168/jds.2016-11612

Wilson, D. M., \& King, J. K. (1995). Production of aflatoxins b1, b2, g1, and g2 in pure and mixed cultures of aspergillus parasiticus and aspergillus flavus. Food Additives and Contaminants, 12, 521-525. https://doi.org/10.1080/02652039509374339

Wu, Q., Jezkova, A., Yuan, Z., Pavlikova, L., Dohnal, V., \& Kuca, K. (2009). Biological degradation of aflatoxins. Drug Metabolism Reviews, 41, 1-7. https://doi.org/10.1080/03602530802563850

Xiong, J. L., Wang, Y. M., Nennich, T. D., Li, Y., \& Liu, J. X. (2015). Transfer of dietary aflatoxin B1 to milk aflatoxin M1 and effect of inclusion of adsorbent in the diet of dairy cows. Journal of Dairy Science, 98, 2545-2554. https://doi.org/10.3168/jds.2013-7842

Zhang, W., He, H., Zang, M., Wu, Q., Zhao, H., Lu, L., ... Jiao, Y. (2017). Genetic Features of Aflatoxin-Associated Hepatocellular Carcinoma. Gastroenterology, 153, 249-262. https://doi.org/10.1053/ j.gastro.2017.03.024

\section{Notes}

Note 1. Brazilian Ministry of Agriculture, Livestock and Supply, in portuguese Ministério da Agricultura, Pecuária e Abastecimento (MAPA) is a Ministry of the Executive Branch of Brazil whose competence is formulate and implement the policies for the development of agribusiness, integrating the technological, organizational and environmental market aspects, to serve the consumers of the country and abroad, promoting food security, generation of income and employment, reduction of inequalities and social inclusion.

Note 2. National Health Surveillance Agency, in portuguese Agência Nacional de Vigilância Sanitária (ANVISA) is an agency them exercises sanitary control of all products and services (national or imported) subject to sanitary surveillance, such as medicines, foods, cosmetics, sanitizers, tobacco products, medical products, blood, blood products and health services.

\section{Copyrights}

Copyright for this article is retained by the author (s), with first publication rights granted to the journal.

This is an open-access article distributed under the terms and conditions of the Creative Commons Attribution license (http://creativecommons.org/licenses/by/4.0/). 